Geochemical sampling at the Jones-Keystone mine Randolph County, North Carolina by

. Arthur R. Kinkel, Jr.

U.S. Geological Survey National Center Reston, Virginia 22092 


\section{Geochemical sampling at the Jones-Keystone mine Randolph County, North Carolina}

\section{by}

Arthur R. Kinkel, Jr.

\section{U.S. Geological Survey National Center \\ Reston, Virginia 22092}

The Keystone or Jones Keystone mine is about 12 miles west of Asheboro, Randolph County, North Carolina in the Denton 15 minute quadrangle. Arvid stromquist and I sampled the large open pits in October 1966 (fig. 1). The samples, except those in the bottom of the southwest pit, are on the walls of the pit and are a mixture of soil and saprolite.

The host rock of the deposit is a sheared sericitized pyritized rhyolite, part of which is probably pyroclastic. Silicified and pyritized zones constitute the ore; there are very few quartz veins and these appear to be barren. Pardee and Park (1948) give the history of the mine. Emmons (1856) reported that the ore mined prior to 1856 contained about $5 \mathrm{ppm}$ gold and was soft surface material (saprolite). Our samples confirm earlier reports that the gold was in rich seams and that the bulk of this material was low grade. Copper and arsenic are unusually high in the surface material in this deposit compared with other deposits in the slate belt which I have sampled. The deposit as exposed in pits appears to follow the schistosity. The northeasterly 
extension is under low ground with no outcrop. The southwesterly extension is marked by a few shallow pits and is all on high ground with considerable outcrop.

Stromquist, who has mapped the geology. in the vicinity of the Jones-Keystone mine believes that the deposit is on a northeast trending fracture or shear zone which is at an angle to bedding as determined by larger rock units. This north east trending shoar zone is in line with the Loughlin mine, which is 1.7 miles southeast of the JonesKeystone mine. A grab sample of the dump of the Loughlin mine by Stromquist contained $6.8 \mathrm{ppm}$ gold and a sample on a small hill $0.3 \mathrm{miles}$ northwest of the Loughlin mine contained $2.06 \mathrm{ppm}$ gold.

If stromquist is correct in believing that the ore deposits were formed only where the shear zones crossed favorable beds, the potential of the Jones-Keystone deposit along the strike would be limited to the bed in which it is found, as would the deposit at the Loughlin mine. It appears from Stromquist's regional mapping that these deposits cannot be on the same stratigraphic zone, yet at each deposit bedding and schistosity appear to be parallel as well as can be determined, and the lithology is identical. Outcrop is inadequate to resolve this problem. I believe that exploration at the Jones-Keystone deposit might outline a fairly large deposit of low grade gold ore, as mineralization appears extensive over several hundred feet of width, and the deposit has not been explored along strike or down dip. Bands of strongly pyritized rock suggest that a ground EM survey should be the first exploration method used. 


\section{References cited}

Emmons, Ebenezer, 1856, Geological report ofthe midland counties of North Carolina: North Carolina Geol. Survey, Henry D. Turner, Raleigh, 351 p.

Pardee, J.T., and Park, C.F., Jr., 1948, Gold deposits of the Southern Piedmont: U.S. Geol. Survey Prof. Paper 213, 156 p.

Stromquist, Arvid A., Choquette, Philip W., sundelius, Harold W., 1971, Geologic map of the Denton quadrangle, central North Carolina: U.S. Geol. Survey Geol. Quad. Map GQ-872, scale 1:62,500. 

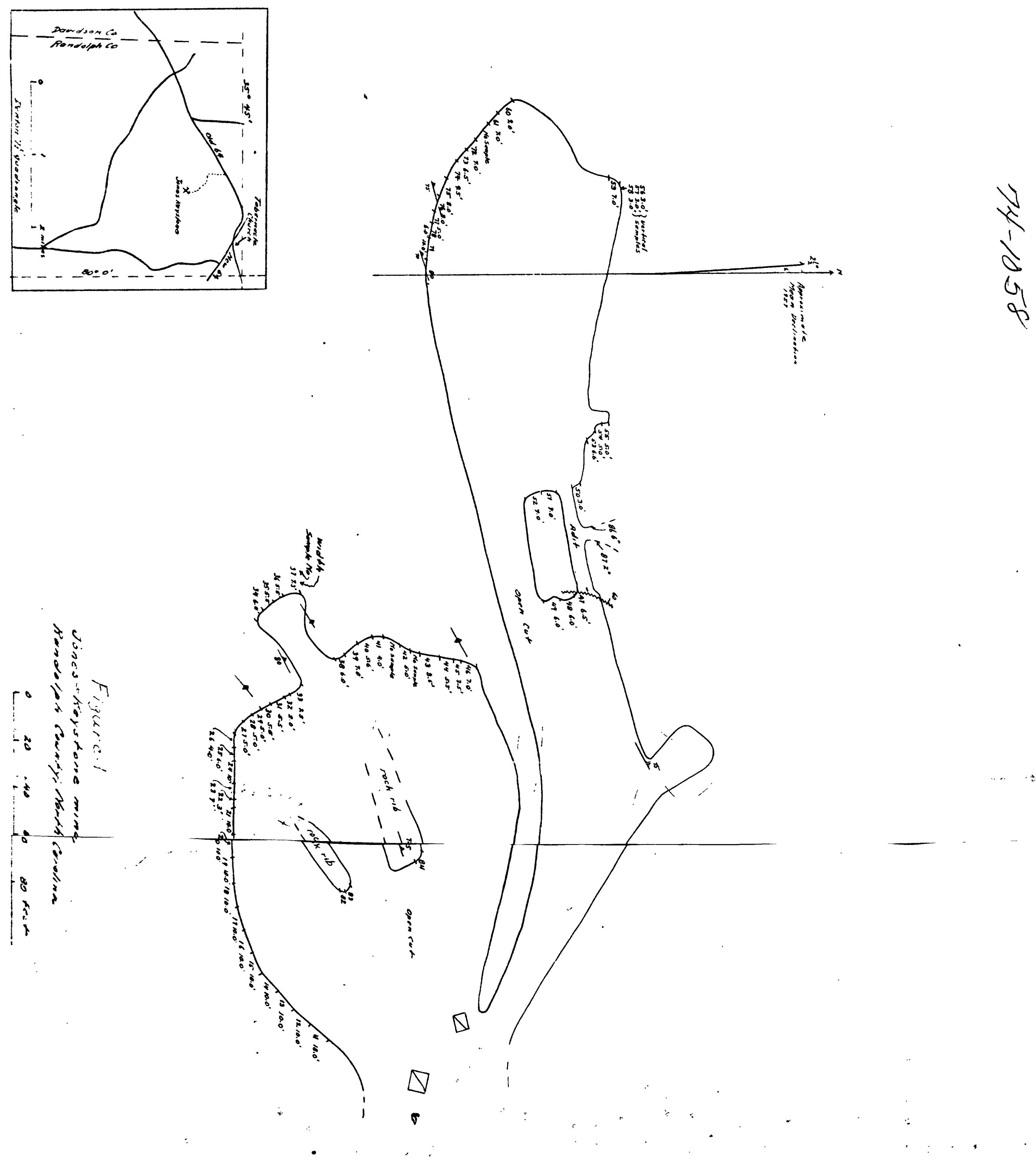

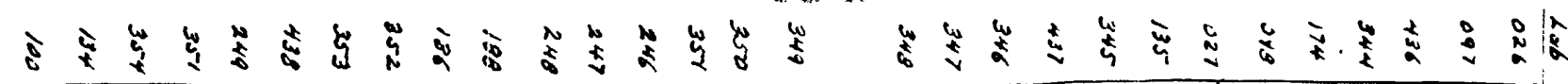

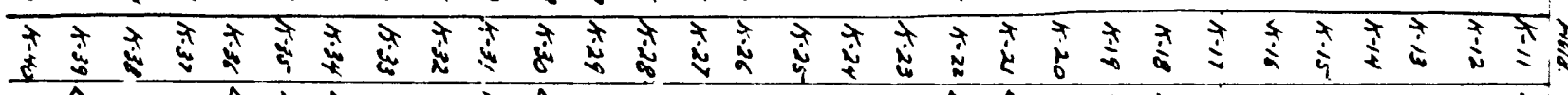

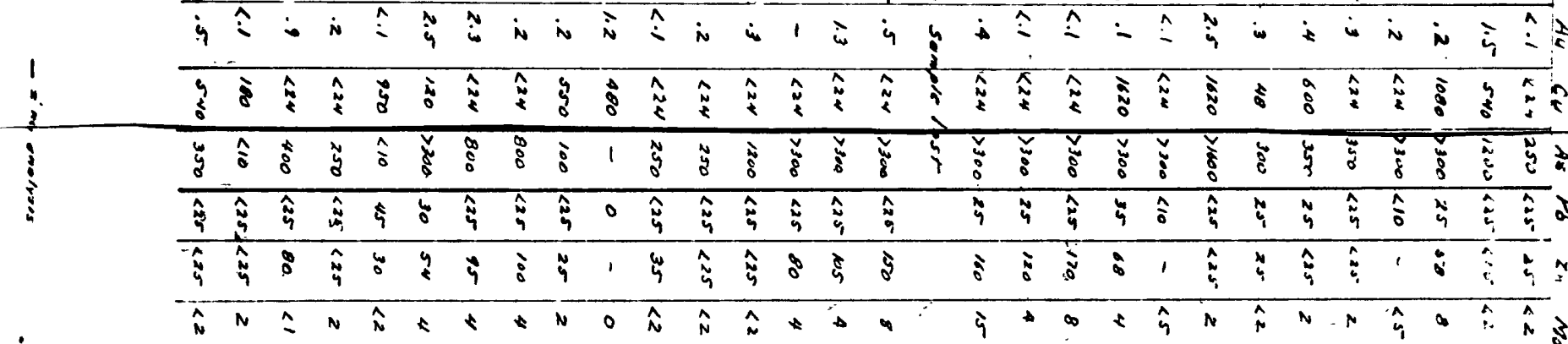

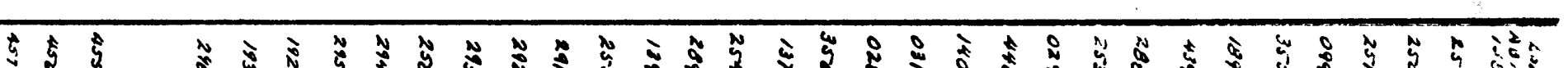

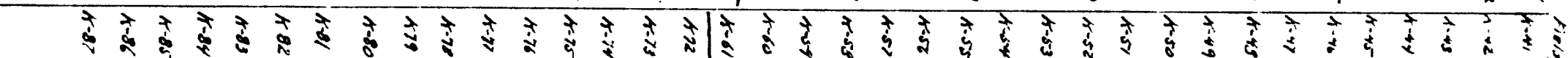

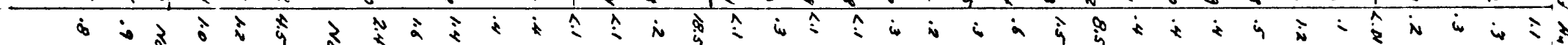
-

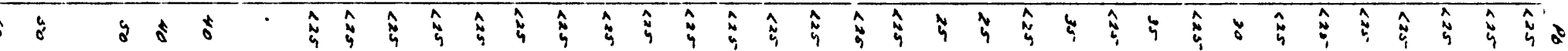

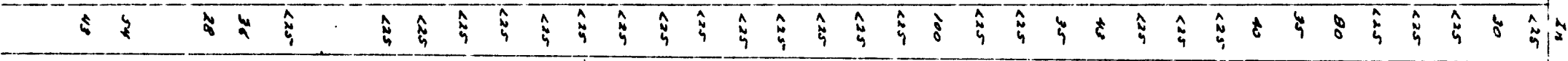
Q 